Research article

urn:1sid:zoobank.org:pub:9135A958-6E83-4E24-878B-388BD206E49B

\title{
A redescription of Harpactea dufouri (Thorell, 1873) (Araneae, Dysderidae), its occurrence outside the Balearic Islands, and some notes on the corticalis group of the genus
}

\author{
Jan BOSSELAERS ${ }^{1, *} \&$ Johan VAN KEER ${ }^{2}$ \\ ${ }^{1}$ Royal Museum for Central Africa, B-3080 Tervuren, Belgium. \\ ${ }^{2}$ Bormstraat 204, bus 3, B-1880 Kapellen op den Bos, Belgium. \\ *Corresponding author: dochterland@telenet.be \\ 2Email: johan.van.keer1@telenet.be \\ ${ }^{1}$ urn:Isid:zoobank.org:author:D6AD7414-3540-4F06-8631-8873450AA90C \\ ${ }^{2}$ urn:1sid:zoobank.org:author:33B65250-686B-44B7-B5E4-6B63203F6F3C
}

\begin{abstract}
Harpactea dufouri (Thorell, 1873) was collected in the Gavarres protected natural area in Catalonia, Spain. The specimens were compared with specimens from Mallorca, Balearic Islands, and found to be conspecific. The female of the species is described here for the first time. The new finding proves that Harpactea dufouri occurs outside the Balearic Islands. The species, however, may be endemic to Catalonia.
\end{abstract}

Keywords. Catalonia, corticalis group, biodiversity, endemism, Harpacteinae.

Bosselaers J. \& Van Keer J. 2016. A redescription of Harpactea dufouri (Thorell, 1873) (Araneae, Dysderidae), its occurrence outside the Balearic Islands, and some notes on the corticalis group of the genus. European Journal of Taxonomy 222: 1-13. http://dx.doi.org/10.5852/ejt.2016.222

\section{Introduction}

The genus Harpactea Bristowe, 1939 (type species: Harpactea hombergi (Scopoli, 1763)) is the second most speciose genus of the family Dysderidae (Řezáč 2008). The World Spider Catalog (2016) lists 175 valid and accepted species for the genus, which is almost one third of the 534 species described for the family. The focus of distribution of the genus is the Mediterranean area, extending to the Caspian region in the East, and, for some species, to central and northern Europe in the North. Interestingly, almost all species of Harpactea have a relatively small distribution area. Only H. hombergi (Scopoli, 1763), H. lepida (C.L. Koch, 1838), H. rubicunda (C.L. Koch, 1838) and H. saeva (Herman, 1879) are widespread species. The majority of Harpactea species have been described after the publication of Roewer's first spider catalogue (1942). Indeed, Roewer (1942) lists only 26 species that are presently considered as valid species belonging to Harpactea. Most of the additional Harpactea species have since been described by Alicata, who described 12 species (Alicata 1966a, 1966b, 1966c, 1973, 1974), Brignoli, who described 35 species (Brignoli 1974, 1976, 1977, 1978a, 1978b, 1978c, 1979a, 1979b, 1979c, 1979d, 1980a, 1980b, 1984), Bosmans and coworkers, who described 31 species (Beladjal \& 
Bosmans 1997; Bosmans \& Beladjal 1989, 1991; Russell-Smith \& Bosmans 2011; Van Keer \& Bosmans 2009), Dunin, who described 23 species (Dunin 1989, 1991, 1992a, 1992b, 1993), and Dimitrov, Lazarov and Naumova, who described 11 species (Dimitrov 1997; Dimitrov \& Lazarov 1999; Lazarov 2006a, 2006b, 2008a, 2008b, 2009a, 2009b, 2010; Lazarov \& Naumova 2010). Among the 172 species presently known, 111 are known from Europe (including Ukraine) and the eastern Mediterranean (Turkey, Lebanon and Israel), 26 from the Caucasus and the region around the Caspian sea, and 35 from North Africa (Algeria and Tunisia). Among the European species, 16 have been reported from the Iberian peninsula (including the Balearic Islands): H. aeruginosa Barrientos, Espuny \& Ascaso, 1994, H. algarvensis Ferrández, 1990, H. blasi Ribera \& Ferrández, 1986, H. dufouri (Thorell, 1873), H. fageli Brignoli, 1980, H. gaditana Pesarini, 1988, H. hispana (Simon, 1882), H. hombergi (Scopoli, 1763), H. magnibulbi Machado \& Ferrández, 1991, H. minoccii Ferrández, 1982, H. ortegai Ribera \& De Mas, 2003, H. proxima Ferrández, 1990, H. skiakyi Pesarini, 1988, H. serena (Simon, 1907), H. stalitoides Ribera, 1993 and H. subiasi Ferrández, 1990. Thirteen of these species are endemic (Cardoso \& Morano 2010: 18).

The authors made a one week field trip to the Gavarres protected natural area in Catalonia, a $300 \mathrm{~km}^{2}$ hill massif in the northernmost part of the Catalonian coastal range, characterised by an amazing biodiversity (Bosselaers 2004, Bosselaers in prep.). On this occasion, the junior author collected six specimens of Harpactea dufouri, formerly only known from the Balearic Islands. This rare species, including the hitherto unknown female, is redescribed and discussed below.

\section{Material and methods}

Specimens were observed, photographed and drawn using Euromex MIC465 and Olympus SZX9 stereo microscopes. For stereo microscope photographs, a Praktica DC440 digital camera was used. Details of the male palp and the vulva were studied with a Zeiss Axio Imager A1 microscope equipped with a Canon Powershot G6 digital camera. The image series obtained were stacked with Zerene Stacker version 1.04 build T201411272115. The vulva was cleaned for microscopy with trypsin (Sigma) for $24 \mathrm{~h}$ at room temperature an subsequently cleared in methyl salicylate for observation. The male palp was immobilized in Schwarzkopf "Freezing Gel Extreme 5", a transparent vinylpyrrolidone-vinylacetate copolymer (CAS 25086-89-9) / carbomer gel (Schröder et al. 2000; Schulze zur Wiesche 2006). All measurements are in millimetres. The format for leg spination follows Platnick \& Shadab (1975), amended for ventral spine pairs according to Bosselaers \& Jocqué (2000: 307). Leg spination is also illustrated in a schematic representation (Fig. $1 \mathrm{E}-\mathrm{G}$ ) where $\mathrm{pl}$, do, $\mathrm{rl}$ and ve sides of leg articles are flattened as a folding net (Dürer 1525).

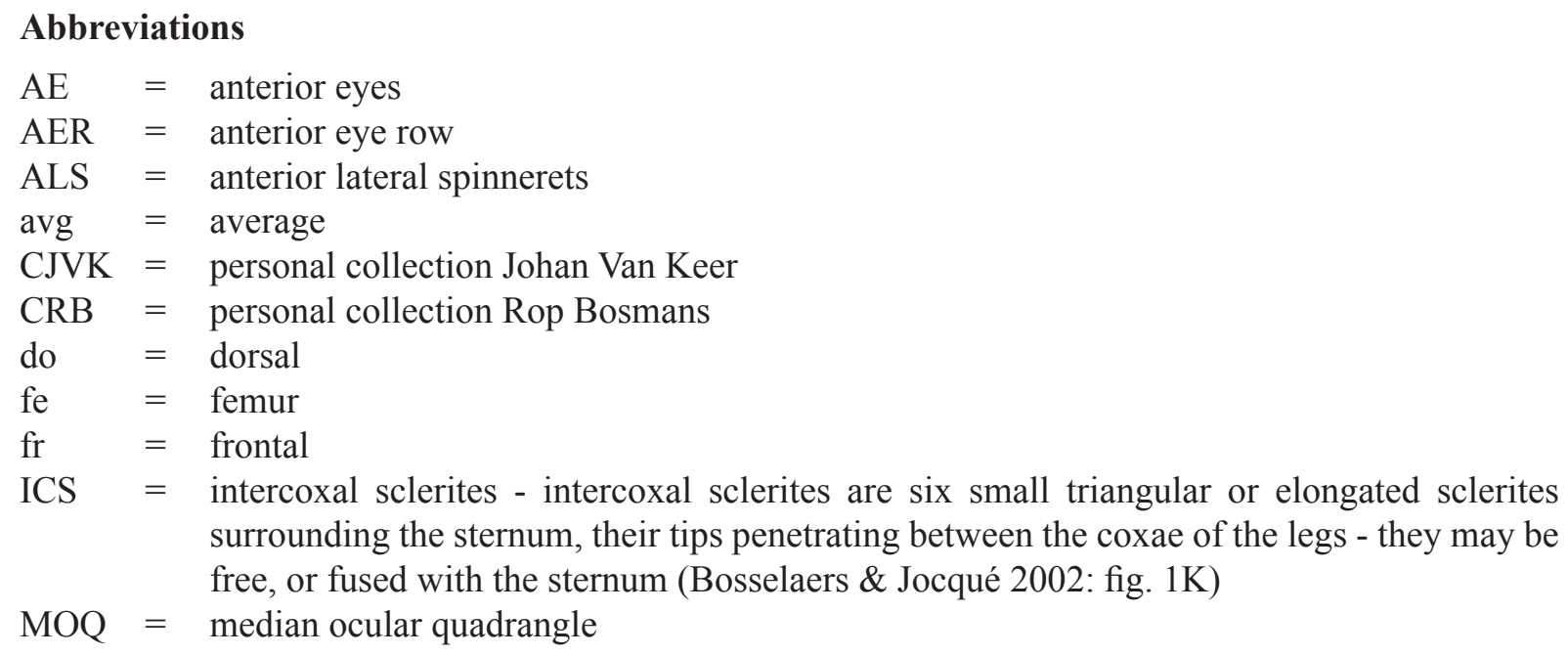




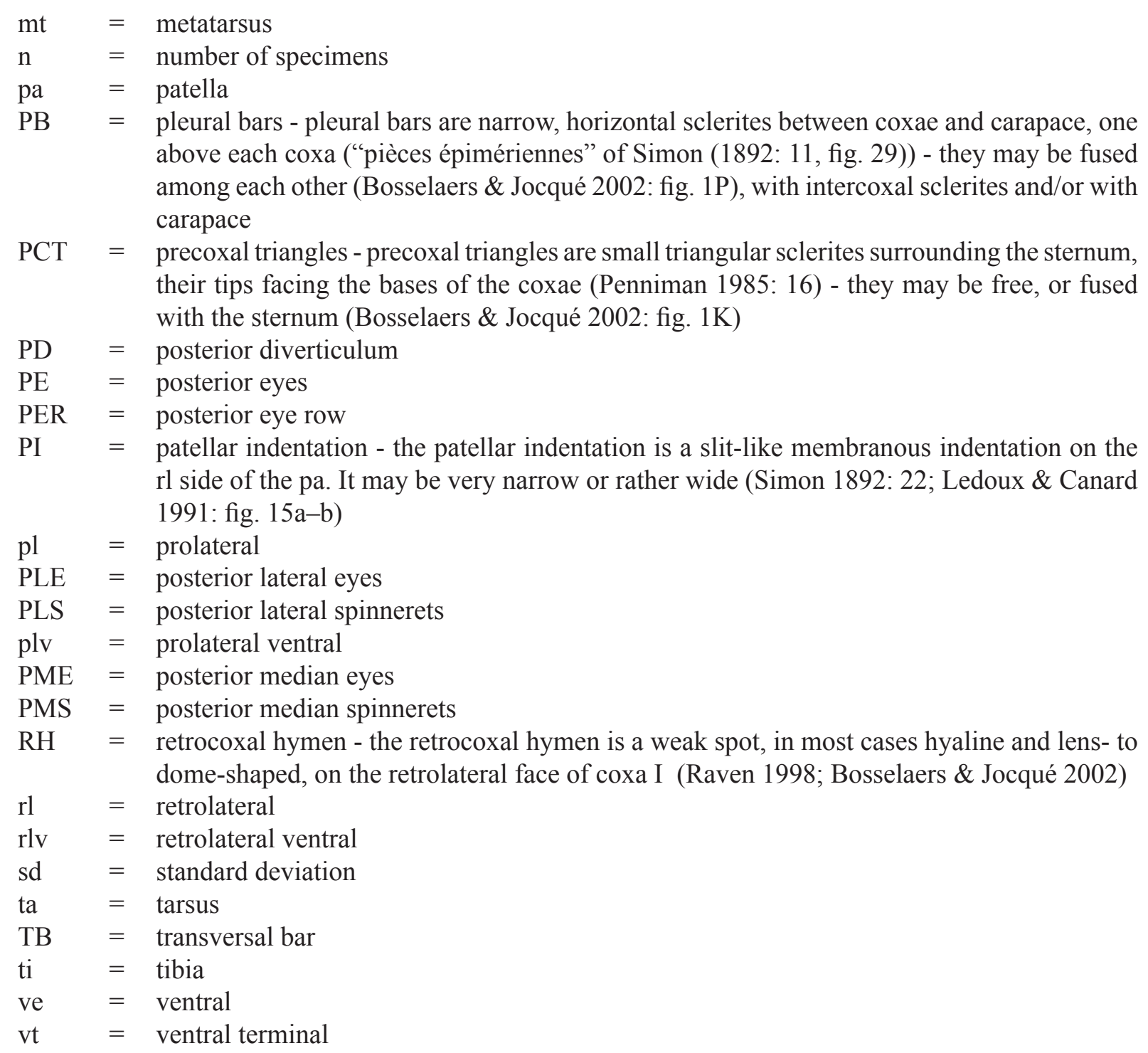

\section{Collections}

$\mathrm{BMNH}=$ British Museum of Natural History, London, UK

CJVK = personal collection Johan Van Keer

$\mathrm{CRB}=$ personal collection Rop Bosmans

IZPAN = Museum and Institute of Zoology PAS, Warsaw, Poland

MCZ = Museum of Comparative Zoology, Harvard University, Cambridge, MA, USA

MNHN = Muséum national d' Histoire naturelle, Paris, France

MRSN = Museo Regionale di Scienze Naturali, Torino, Italy

MSNG = Museo civico di Storia naturale "Giacomo Doria", Genova, Italy

$\mathrm{NRM}=$ Naturhistoriska Riksmuseet, Stockholm, Sweden

ZMUC $=$ Zoologisk Museum Kopenhagen, Denmark 


\title{
Results
}

\author{
Class Arachnida Cuvier, 1812 \\ Order Araneae Clerck, 1757 \\ Family Dysderidae C.L. Koch, 1837 \\ Genus Harpactea Bristowe, 1939 \\ Harpactea dufouri (Thorell, 1873)
}

Figs 1-2

Harpactes dufourii Thorell, 1873: 561.

Harpactea dufouri-Denis 1961: 236, fig. 1. —Alicata 1966a: 211, fig. 61. — Brignoli 1979c: 114, figs 2-3. - Le Peru 2011: 268, fig. 400.

\section{Diagnosis}

Harpactea dufouri differs from H. corticalis (Simon, 1882) by the more slender bulbus of the male palp, the more straight conductor and embolus and the larger number of spines on femora III and IV.

Harpactea dufouri somewhat resembles H. heizerensis Bosmans \& Beladjal, 1991, but differs from it by the knife-shaped, pointed conductor with very sharp teeth, the posterior diverticulum of the vulva consisting of a small ventral and a larger dorsal lobe and by the larger number of spines on femorae III and IV.

\section{Material examined}

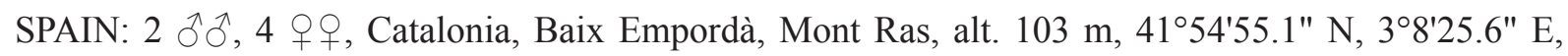
former quarry converted into lake and picnick area, under stones, 23 Oct. 2013, Van Keer leg. (CJVK) (Fig. 1H); 2 ㅅํ, 2 우우, Balearic Islands, Mallorca, Banyalbufar W., Font de Sant Merita, Platanus forest, alt. $150 \mathrm{~m}$, sifting litter, 1 Apr. 2003, R. Bosmans leg. et det. (CRB).

\section{Description}

\section{Male}

Largest specimen Mont Ras, total length $5.50(\operatorname{avg}(n=4) 4.48$, sd 1.08). Carapace length 2.16, width 1.60 , yellowish brown with faint grey radial striae, more reddish brown in cephalic region, smooth. Cephalic region slightly wider than half the carapace width, three times as wide as the eye group (Fig. 2A-B). Fovea weak and thin, length 0.32 , anterior end 1.42 from front end of carapace.

MOQ length 0.22 , anterior width 0.26 , posterior width 0.16 , AER width 0.26 , PER width 0.34 . All six eyes ringed with black, PE clear pearly white, almost touching, diameter of PLE 1.5 times PME. AE as large as PLE, pearly white, subquadratic, separated by half their diameter. PER procurved in both do and fr view. Clypeus vertical, 0.05, equal to half the diameter of AE.

Chilum single, triangular, brown and sclerotised. Chelicerae brown, slightly rugose, anterior rim with two teeth close to fang tip, the bigger one furthest from tip. Posterior rim with two small, widely spaced teeth. Labium twice as long as wide, with small anterior notch. Endites long and parallel, with serrula and bluntly pointed anterior end. Exterior margin notched.

Sternum yellow, rebordered, oval, narrowed frontally and protruding between all coxae. Sternum length 1.45 , width 1.05 , surface smooth, but with tiny, evenly spaced punctures. Four pairs of heavily sclerotised, sharply pointed, dark brown PCT. ICS and PB fused and surrounding coxae. 


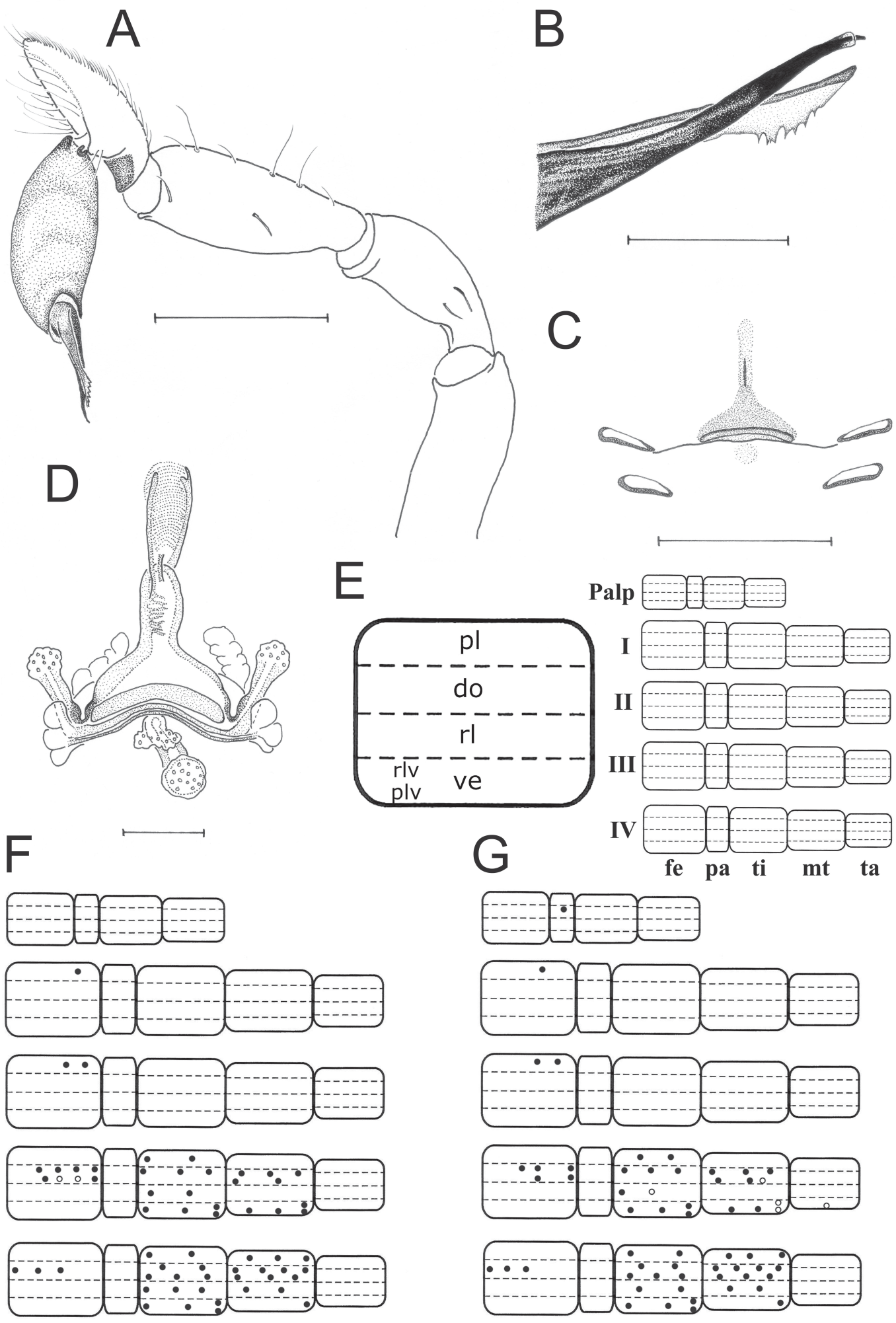

Fig. 1. Harpactea dufouri (Thorell, 1873), Mont Ras specimens. A. Male palp, prolateral view. B. Tip of male embolus and conductor, retrolateral view. C. Endogyne, external ventral view, uncleared. D. Cleared vulva, ventral view. E. Leg spination scheme, legend. F. Leg spination scheme of male. White dots are spines present on one leg and absent on the other. G. Leg spination scheme of female. White dots are spines present on one leg and absent on the other. Scale bars: A, C $=0.5 \mathrm{~mm} ; \mathrm{B}, \mathrm{D}=100 \mu \mathrm{m}$. 


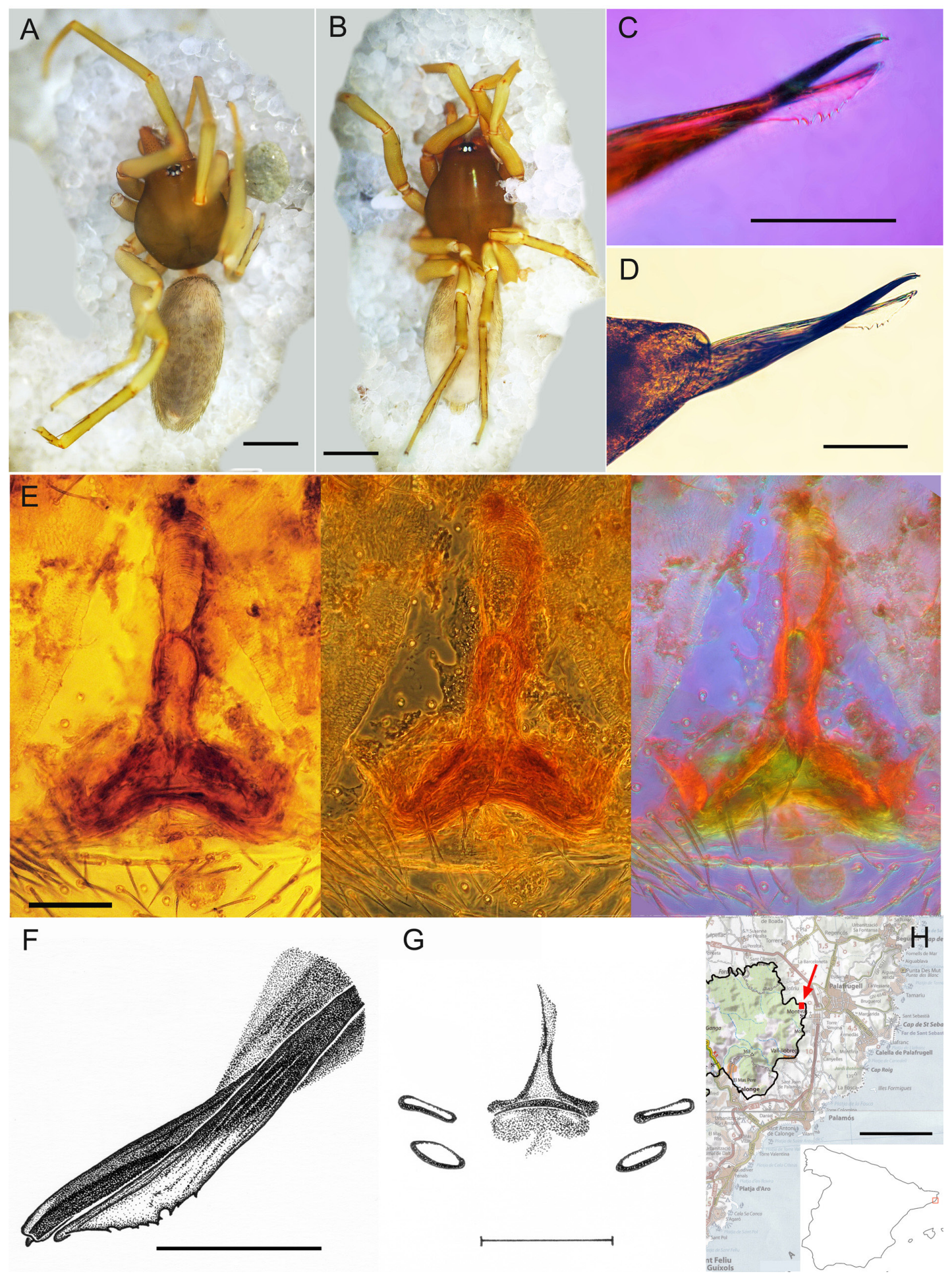

Fig. 2. A-G. Harpactea dufouri (Thorell, 1873), Mont Ras specimens, except F-G. A. ̊̊, dorsal view. B. 9 , dorsal view. C. Tip of male embolus and conductor, retrolateral view, Nomarski interference contrast. D. Tip of male embolus and conductor, retrolateral view, bright field. E. Cleared vulva, ventral view. Left: bright field, middle: phase contrast, right: Nomarski interference contrast. F. Tip of male embolus and conductor, Banyalbufar specimen. G. Endogyne, external ventral view, Banyalbufar specimen. - H. Map showing the Mont Ras site of Harpactea dufouri (red square), the Gavarres are delimited by a black line. Scale bars: $A-B=1 \mathrm{~mm} ; \mathrm{C}-\mathrm{F}=100 \mu \mathrm{m} ; \mathrm{G}=0.5 \mathrm{~mm} ; \mathrm{H}=5 \mathrm{~km}$. 
Legs orange yellow, shiny. Leg formula 1423. No RH, no trochanter notch. PI very narrow, extending along the whole length of pa III, but restricted to the basal third in pa I, II and IV. Ventral terminal preening brush present on $\mathrm{mt}$ III and IV. Tarsi with three claws, no claw tufts or tenent hairs. Leg spination (Fig. 1F): fe: I pl 0-0-1; II pl 0-1-1; III do 2-2-2-2; IV do 1-1-1-0; ti: III pl 1-0-1 do 1-1-1 rl 1-1-0 ve $1-1-2$; IV pl 1-0-1 do 2-1-2 rl 1-1-1 ve $1-1-2$; mt: III do $2-2-1$ ve $1-1-2$; IV pl 1-1-1 do $2-2-1-2$ rl $1-1-0$ ve $0-0-1$.

Leg measurements:

\begin{tabular}{ccccccc}
\hline & fe & pa & ti & mt & ta & Total \\
\hline I & 1.89 & 1.32 & 1.84 & 1.66 & 0.55 & 7.26 \\
II & 1.58 & 1.05 & 1.45 & 1.34 & 0.50 & 5.92 \\
III & 1.53 & 0.53 & 1.00 & 1.26 & 0.45 & 4.76 \\
IV & 1.97 & 0.82 & 1.71 & 1.92 & 0.58 & 7.00 \\
\hline
\end{tabular}

Abdomen grey, covered with thin, pointed grey setae becoming coarser on anterior rim (Fig. 2A). ALS subcylindrical, stout, separated by $1 / 4$ of their length. PMS thin and conical, PLS thin, subcylindrical, separated by half their length.

Male palp as illustrated (Figs 1A-B, 2C-D, F), with spindle-shaped bulbus, straight, black, simple, pointed embolus and flat, hyaline conductor with a broadened, sharply toothed tip. Both male specimens captured in Mont Ras had the right palp missing. The loss of the palp occurred quite some time before capture, as the scar had completely healed and was sclerotised.

\section{Female}

Largest specimen Mont Ras, total length $5.75(\operatorname{avg}(n=6) 4.70$, sd 0.78). Carapace length 2.10, width 1.56, dark yellowish brown with faint grey radial striae, smooth (Fig. 2B). Cephalic region as in male. Fovea weak and thin, length 0.34 , anterior end 1.32 from front end of carapace.

MOQ length 0.21 , anterior width 0.25 , posterior width 0.18 , AER width 0.25 , PER width 0.37 . Eyes as in male. Clypeus vertical, 0.03 , equal to one third diameter of AE.

Chilum, chelicerae, labium and endites as in male.

Sternum, PCT, ICS and PB as in male. Sternum length 1.32, width 1.03.

Legs orange yellow, shiny. Leg formula 4123. No RH, no trochanter notch. PI, ventral terminal preening brush and tarsi as in male. Leg spination (Fig. 1G): fe: I pl 0-0-1; II pl 0-1-1; III do 0-1-2-2; IV do 1-1-1-0; ti: III pl 1-0-1 do $1-1-1$ rl 1-(0,1)-0 ve $1-1-2$; IV pl 1-0-1 do $2-1-2$ rl 1-0-1 ve $1-1-2$; mt: III do $2-2-(1,2)$ ve $1-1-(0,2)$; IV pl $1-1-1$ do $2-2-1-2$ rl $1-1-0$ ve $0-0-1$; ta: III ve $0-(0,1)-0$.

Leg measurements:

\begin{tabular}{ccccccc}
\hline & fe & pa & ti & mt & ta & Total \\
\hline I & 1.58 & 1.05 & 1.34 & 1.18 & 0.45 & 5.60 \\
II & 1.39 & 0.92 & 1.21 & 1.05 & 0.39 & 4.97 \\
III & 1.18 & 0.50 & 0.79 & 1.00 & 0.34 & 3.81 \\
IV & 1.71 & 0.79 & 1.47 & 1.71 & 0.55 & 6.23 \\
\hline
\end{tabular}

Abdomen pinkish grey, covered with thin, pointed grey setae (Fig. 2B). ALS conical, touching. PMS thin and conical, PLS thin, subcylindrical, separated by half their length. 
Epigyne essentially absent, all sclerotised parts internal (endogyne, Jocqué \& Dippenaar-Schoeman 2006: 120), but TB ("valva posterodorsale" of Alicata (1964: 4), "transversal bar" of Chatzaki \& Arnedo (2006: 5)) clearly visible from the outside, as illustrated (Figs 1C, 2G). Vulva with pronounced TB, PD (Chatzaki \& Arnedo 2006: 6) consisting of an irregular ventral lobe and a globular dorsal lobe, both with a perforated, glandular aspect (Figs 1D, 2E). Genital atrium (Alicata 1964: 4; Chatzaki \& Arnedo 2006: 5) connected on both posterolateral ends to glandular structures. Additional membranous, transparent pouches also present. Spermatheca sausage-shaped, connected to anterior end of genital atrium (Figs 1D, 2E).

\section{Distribution}

Only known from the Balearic islands and the Northern part of the Catalonian coastal range (Fig. 1H).

\section{Discussion}

The genus Harpactea has a quite homogeneous somatic morphology, but there is considerable genitalic diversity, suggesting the existence of a number of subgenera, or even the possibility that several related genera are involved. Simon (1893: 318) was the first to suggest a division of Harpactes Templeton, 1835 (preoccupied as the bird name Harpactes Swainson, 1833 (Trogonidae) and replaced by Harpactea by Bristowe 1939: 5) in three subgroups. However, only one of these groups concerns species presently considered as true Harpactea, the other two being composed of species belonging to Dasumia Thorell, 1875, Harpactocrates Simon, 1914 and Parachtes Alicata, 1964.

The first to suggest a subdivision of Harpactea as presently delimited is Alicata (1966a: 192). He bases his subdivision on genitalic characteristics and recognises three large groups: one consisting of species reminiscent of Dasumia; another, consisting of two subgroups, having a male bulbus with a complex set of apophyses and including $H$. hombergi; and a third group, characterised by a simple, elongated bulbus with 1-3 apophyses (embolus, conductor, pseudoconductor (Brignoli 1978b: 481)), consisting of four subgroups and including H. corticalis (Simon, 1882). Brignoli (1978b: 481) recognises two groups: a corticalis group with a simple set of apophyses on the bulbus (consisting of six subgroups), and a hombergi group with complex apophyses (consisting of four subgroups). Deeleman-Reinhold (1993: 130) recognises four groups, based on a combination of genitalic and leg spination characters: a corticalis group, largely similar to Alicata's and Brignoli's group with a simple male bulbus, a hombergi group characterised by a complex male bulbus, a lepida group with a lamellar conductor and a wide PD, and a rubicunda group with a large, entirely membranous PD. Beladjal \& Bosmans (1997: 24) follow the subdivision of Brignoli (1978b), but add a third group, the auriga group, characterised by a globular bulbus and a long, filiform embolus.

None of these subdivisions is entirely satisfactory, as they are purely phenetic and no cladistic analysis was performed. Although the hypothesis sounds plausible, there is no proof that the corticalis group is "le groupe le plus primitif" (Beladjal \& Bosmans 1997: 24), as no phylogenetically valid outgroup comparison (Watrous \& Wheeler 1981; Maddison et al. 1984) is available. There is even no solid proof that this group actually exists, id est, that it is not polyphyletic.

Nevertheless, provisory as they are, the subdivisions proposed to date have some practical advantage, facilitating an overview of the genitalic diversity in the large genus Harpactea. Moreover, it has to be admitted that the corticalis group is indeed "abbastanza omogeneo" and "abbastanza ben delimitato dagli altri" (Brignoli 1978b: 481), so it can be retained for the time being, until the enormous work of a cladistic analysis of Harpactea has been undertaken.

Scrutiny of the available literature suggests that such a corticalis group should at least include $H$. acuta Beladjal \& Bosmans, 1997, H. angustata (Lucas, 1846), H. arguta (Simon, 1907), H. blasi Ribera \& 
Ferrández, H. carusoi Alicata, 1974, H. corticalis (Simon, 1882), H. dufouri (Thorell, 1873), H. dumonti Bosmans \& Beladjal, 1991, H. gaditana Pesarini, 1988, H. gennargentu Wunderlich, 1995, H. gridellii (Caporiacco, 1951), H. heizerensis Bosmans \& Beladjal, 1991, H. innupta Beladjal \& Bosmans, 1997, H. kalaensis Beladjal \& Bosmans, 1997, H. kareli Bosmans \& Beladjal, 1991, H. major (Simon, 1911), H. mertensi Bosmans \& Beladjal, 1991, H. minuta Alicata, 1974, H. mitidjae Bosmans \& Beladjal, 1991, H. monicae Bosmans \& Beladjal, 1991, H. muscicola (Simon, 1882), H. oranensis Bosmans \& Beladjal, 1991, H. ouarsenensis Bosmans \& Beladjal, 1991, H. piligera (Thorell, 1875), H. punica Alicata, 1974, H. senalbensis Beladjal \& Bosmans, 1997, H. sicula Alicata, 1966, H. sinuata Beladjal \& Bosmans, 1997, H. undosa Beladjal \& Bosmans, 1997, H. yakourensis Beladjal \& Bosmans, 1997, and $H$. zannonensis Alicata, 1966. These 31 species (one fifth of the genus) all occur in the western Mediterranean and they all have small distribution areas.

Three of the 16 Iberic Harpactea species can be attributed to the corticalis group with some confidence: H. blasi, H. dufouri and H. gaditana.

The specimens collected in Mont Ras were at first considered to be a new species by the authors. Indeed, the illustrations of the male palp of H. dufouri in Denis (1961), Alicata (1966a, drawn after Denis) and Le Peru (2011, a synthetic computer drawing) are insufficient to identify the species with certainty. Nevertheless, Brignoli (1979c: fig. 2) illustrates a toothed conductor that is quite similar to the one of the Mont Ras specimens (Fig. 1B, 2C-D), as rightly pointed out by Crespo when refereeing a previous version of this paper. Unfortunately, the type specimen of $H$. dufouri is not present in NRM, where it would normally be kept, given the fact that it was collected by the Swede F. Söderlund (Thorell 1873: 561). The type could also not be traced in BMNH, IZPAN, MCZ, MNHN, MRSN, MSNG or ZMUC. As a result, the type of $H$. dufouri must be considered lost.

However, four adult specimens of $H$. dufouri collected by Bosmans in Mallorca could be studied. They turned out to be conspecific with the Mont Ras material (Figs 1B-C, 2F-G). It can be concluded that $H$. dufouri is not an island endemic, but also occurs in the Catalonian coastal region. The female, described here for the first time, has a genitalic morphology typical for the corticalis group of Harpactea.

\section{Acknowledgements}

The authors are grateful to Monique Luyten for hospitality and daily care and to Joan Botey i Serra for encouragement and the permission to collect on his private property in the Gavarres. Luís Carlos Crespo and an anonymous referee are thanked for their interesting comments that helped improve the manuscript. Many thanks are also due to the collection curators and arachnologists that were helpful in trying to locate the holotype of Harpactea dufouri: Gonzalo Giribet, Laura Leibensperger (MCZ); Pietro Passerin d'Entrèves, Elena Gavetti (MRSN); Maria Tavano (MSNG); Christine Rollard (MNHN); Jerzy Proszynski, Wioletta Wawer (IZPAN); Nikolaj Scharff (ZMUC); Janet Beccaloni (BMNH); Kjell Arne Johanson, Torbjörn Kronestedt, Karin Sindemark Kronestedt (NRM). Rop Bosmans is gratefully acknowledged for the specimens of Harpactea dufouri from Mallorca.

\section{References}

Alicata P. 1964. Le specie italiane di Harpactocrates e di Parachtes n. gen. (Araneae, Dysderidae). Annuario dell 'Istituto e Museo di Zoologia dell'Universita di Napoli 16 (3): 1-40.

Alicata P. 1966a. Le Harpactea (Araneae, Dysderidae) della fauna italiana e considerazioni sulla loro origine. Atti dell' Accademia Gioenia di Scienze Naturali in Catania (6) 18: 190-221. 
Alicata P. 1966b. Considerazioni sulla sistematica, evoluzione e biogeografia di alcuni generi di Dysderidae (Araneae). Bollettino delle sedute della Accademia Gioenia di Scienze Naturali in Catania (4) 8: 810-821.

Alicata P. 1966c. Una nuova specie di Harpactea delle isole Pontine (Araneae, Dysderidae). Fragmenta Entomologica 4: 113-115.

Alicata P. 1973. I Dysderidae (Araneae) delle Eolie, delle Egadi e di Ustica. Lavori della Società Italiana di Biogeografia (N.S.) 3: 341-353.

Alicata P. 1974. Le Harpactea Bristowe (Araneae, Dysderidae) del Nord Africa. Animalia 1: 3-24.

Beladjal L. \& Bosmans R. 1997. Nouvelles données sur le genre Harpactea Bristowe en Algérie (Araneae, Dysderidae). Revue arachnologique 12 (2): 9-29.

Bosmans R. \& Beladjal L. 1989. Les araignées du genre Harpactea Bristowe (Araneae: Dysderidae) du Parc National de Chrea (Algérie). Biologisch Jaarboek Dodonaea 56: 92-104.

Bosmans R. \& Beladjal L. 1991. Une douzaine de nouvelles espèces d'Harpactea Bristowe d'Algérie, avec la description de trois femelles inconnues (Araneae: Dysderidae). Revue Suisse de Zoologie 98 (3): 645-680. http://dx.doi.org/10.5962/bhl.part.82075

Bosselaers J. 2004. Some myxomycetes from the Baix Empordà region, Catalunya, Spain Acta Botanica Croatica 63 (1): 1-15.

Bosselaers J. in prep. Spiders (Arachnida, Araneae) of the Gavarres (Catalonia, Spain) and the adjacent coastal region - Part I: 2012-2013. Newsletter of the Belgian Arachnological Society.

Bosselaers J. \& Jocqué R. 2000. Studies in Corinnidae: transfer of four genera and description of the female of Lessertina mutica Lawrence 1942. Tropical Zoology 13: 305-325. http://dx.doi.org/10.1080/ $\underline{03946975.2000 .10531138}$

Bosselaers J. \& Jocqué R. 2002. Studies in Corinnidae: cladistic analysis of 38 corinnid and liocranid genera, and transfer of Phrurolithinae. Zoologica Scripta 31: 241-270. http://dx.doi.org/10.1046/j.1463$\underline{6409.2002 .00080 . \mathrm{x}}$

Brignoli P.M. 1974. Ragni di Grecia VI. Specie nuove o interessanti delle isole Ionie e della Morea (Araneae). Revue Suisse de Zoologie 81 (1): 155-175. http://dx.doi.org/10.5962/bhl.part.75999

Brignoli P.M. 1976. Ragni di Grecia IX. Specie nuove o interessanti delle famiglie Leptonetidae, Dysderidae, Pholcidae ed Agelenidae (Araneae). Revue Suisse de Zoologie 83 (3): 539-578. http:// dx.doi.org/10.5962/bhl.part.91452

Brignoli P.M. 1977. Ragni di Grecia X. Nuovi dati sulla Grecia continentale ed insulare (Araneae). Revue Suisse de Zoologie 84: 937-954. http://dx.doi.org/10.5962/bhl.part.91369

Brignoli P.M. 1978a. Ragni di Turchia IV. Leptonetidae, Dysderidae ed Agelenidae nuovi o interessanti di grotte della Turchia meridionale (Araneae). Quaderni di Speleologia, Circolo Speleologico Romano 3: $37-54$.

Brignoli P.M. 1978b. Ragni di Turchia V. Specie nuove o interessanti, cavernicole ed epigee, di varie famiglie (Araneae). Revue suisse de Zoologie 85 (3): 461-541. http://dx.doi.org/10.5962/bhl.part.82243

Brignoli P.M. 1978c. Una nuova Harpactea d'Israele (Araneae, Dysderidae). Revue Suisse de Zoologie 85 (2): 349-351. http://dx.doi.org/10.5962/bhl.part.82236

Brignoli P.M. 1979a. Ragni d'Italia XXIX. Dysderidae nuovi o interessanti (Araneae). Bollettino della Società Entomologica Italiana 111: 17-26. 
Brignoli P.M. 1979b. Ragni di Grecia XI. Specie nuove o interessanti, cavernicole ed epigee. Revue Suisse de Zoologie 86 (1): 181-202. http://dx.doi.org/10.5962/bhl.part.82285

Brignoli P.M. 1979c. Sur quelques Dysderidae de France, d'Espagne et de Tunisie (Araneae). Vie et Milieu Série C 28-29: 111-116.

Brignoli P.M. 1979d. Spiders from Turkey, VI. Four new species from the coast of the Black Sea (Araneae). Bulletin of the British Arachnological Society 4: 310-313.

Brignoli P.M. 1980a. Araignées d'Espagne V. Une nouvelle Harpactea de la province de Salamanca (Araneae, Dysderidae). Bulletin de l'Institut Royal des Sciences Naturelles de Belgique 52 (20): 1-4.

Brignoli P.M. 1980b. A new Harpactea from Iran (Araneae, Dysderidae). Bulletin of the British Arachnological Society 5: 95-97.

Brignoli P.M. 1984. Ragni di Grecia XII. Nuovi dati su varie famiglie (Araneae). Revue Suisse de Zoologie 91 (2): 281-321. http://dx.doi.org/10.5962/bhl.part.81881

Bristowe W.S. 1939. The Comity of Spiders. Vol. 1. Ray Society, London.

Cardoso P. \& Morano E. 2010. The Iberian spider checklist (Araneae). Zootaxa 2495: 1-52.

Chatzaki M. \& Arnedo M.A. 2006. Taxonomic revision of the epigean representatives of the spider subfamily Harpacteinae (Araneae: Dysderidae) on the island of Crete. Zootaxa 1169: 1-32.

Deeleman-Reinhold C.L. 1993. The genus Rhode and the harpacteine genera Stalagtia, Folkia, Minotauria, and Kaemis (Araneae, Dysderidae) of Yugoslavia and Crete, with remarks on the genus Harpactea. Revue Arachnologique 10: 105-135.

Denis J. 1961. Quelques araignées de Minorque. Archives de Zoologie Expérimentale et Générale 99: 235-243.

Dimitrov D. 1997. Description of Harpactea strandjica, sp. n. from Bulgaria (Araneae, Dysderidae). Bulletin of the British Arachnological Society 10: 322.

Dimitrov D. \& Lazarov S. 1999. Two new species of Harpactea from Bulgaria (Araneae: Dysderidae). Berichte des Naturwissenschaftlich-Medizinischen Vereins in Innsbruck 86: 127-129.

Dunin P.M. 1989. New spider species of the genus Harpactea from Armenia (Aranei, Dysderidae). Zoologicheskiǔ Zhurnal 68 (7): 142-145.

Dunin P.M. 1991. Spiders of genus Harpactea in the fauna of Azerbaijan (Aranei, Haplogynae, Dysderidae). Zoologicheskiu Zhurnal 70 (9): 76-86.

Dunin P.M. 1992a. New spider species in the genus Harpactea in the Caucasus fauna (Aranei, Haplogynae, Dysderidae). Zoologicheskil Zhurnal 71 (1): 58-62.

Dunin P.M. 1992b. The spider family Dysderidae of the Caucasian fauna (Arachnida Aranei Haplogynae). Arthropoda Selecta 1 (3): 35-76.

Dunin P.M. 1993. A new species of the spider genus Harpactea Bristowe, 1939 from Azerbaijan (Aranei Dysderidae). Arthropoda Selecta 2 (2): 45-46.

Dürer A. 1525. Underweysung der Messung mit dem Zirckel, und Richtscheyt, in Linien, ebnen und gantzen Corporen. Hieronymus Andreas Formschneider, Nuremberg. Available from http://digital.slubdresden.de/fileadmin/data/27778509X/27778509X_tif/jpegs/27778509X.pdf [accessed 28 Dec. 2014].

Jocqué R. \& Dippenaar-Schoeman A.S. 2006. Spider families of the world. Royal Museum for Central Africa, Tervuren. 
Lazarov S. 2006a. A new spider species, Harpactea samuili sp. n., from Bulgaria (Araneae: Dysderidae). In: Deltshev C. \& Stoev P. (eds) European Arachnology 2005. Acta Zoologica Bulgarica Supplement 1: $81-85$.

Lazarov S. 2006b. A new spider species, Harpactea alexandrae sp. n. (Araneae: Dysderidae). Acta Zoologica Bulgarica 58: 13-16.

Lazarov S. 2008a. A new spider species, Harpactea asparuhi sp. nov., from Bulgaria (Araneae: Dysderidae). Revista Ibérica de Aracnología 15: 25-27.

Lazarov S. 2008b. A new spider species Harpactea kubrati sp. n. from Bulgaria (Araneae, Dysderidae). Acta Zoologica Bulgarica 60: 219-221.

Lazarov S. 2009a. Harpactea konradi, a new spider species from Bulgaria (Araneae, Dysderidae). Zootaxa 2140: 33-37.

Lazarov S. 2009b. A new spider species from Bulgaria, Harpactea terveli sp. n. (Araneae, Dysderidae). International Journal of Academic Research 1: 96-98.

Lazarov S. 2010. A new spider species Harpactea krumi sp. n. from Bulgaria (Araneae, Dysderidae). Acta Zoologica Bulgarica 62: 27-31.

Lazarov S. \& Naumova M. 2010. Two new Harpactea species from Bulgaria (Araneae: Dysderidae). Revue Suisse de Zoologie 117 (1): 101-110. http://dx.doi.org/10.5962/bhl.part.117592

Ledoux J.-C. \& Canard A. 1991. Initiation à l'étude systématique des araignées. Aramon, J.-C. Ledoux.

Le Peru B. 2011. The Spiders of Europe, a Synthesis of Data: Volume 1. Atypidae to Theridiidae. Mémoires de la Société Linnéenne de Lyon 2, Société Linnéenne de Lyon, Lyon.

Maddison W.P., Donoghue M.J. \& Maddison D.R. 1984. Outgroup analysis and parsimony. Systematic Zoology 33: 83-103.

Penniman A. 1985. Revision of the britcheri and pugnata groups of Scotinella (Araneae, Corinnidae, Phrurolithinae) with a reclassification of phrurolithine spiders. PhD dissertation, The Ohio State University, Columbus, available through University Microfilms International ( ${ }^{\circ}$ 8510623).

Platnick N.I. \& Shadab M.U. 1975. A revision of the spider genus Gnaphosa (Araneae, Gnaphosidae) in America. Bulletin of the American Museum of Natural History 155: 1-66.

Raven R. 1998. Revision of the Australian genera of the Miturgidae with a preview of their relationships. In: Van der Merwe M., Platnick N.I. \& Sierwald P. (eds) XIVth International Congress of Arachnology, Abstracts: 31 . The Field Museum, Chicago.

Řezáč M. 2008. Description of Harpactea sadistica n. sp. (Araneae: Dysderidae) - a haplogyne spider with reduced female genitalia. Zootaxa 1698: 65-68.

Roewer C.F. 1942. Katalog der Araneae von 1758 bis 1940. 1. Band. Komissions-Verlag von "NATURA", Bremen.

Russell-Smith A. \& Bosmans R. 2011. Two new species of Harpactea from the island of Chios, Greece (Araneae Dysderidae). Bulletin de la Société Royale Belge d'Entomologie 147: 133-136.

Schröder T., Baumscheiper M. \& Poppe E. 2000. Zubereitungen zur Behandlung keratinischer Fasern. German patent DE19907715A1. Deutsches Patent- und Markenamt, München.

Schulze zur Wiesche E. 2006. Moderne Haarpflegemittel. Praxis der Naturwissenschaften - Chemie in der Schule 6 (55): 14-17.

Simon E. 1892. Histoire naturelle des araignées. Tome 1, Premier fascicule. Roret, Paris. http://dx.doi. org/10.5962/bhl.title. 51973 
Simon E. 1893. Histoire naturelle des araignées. Tome 1, Deuxième fascicule. Roret, Paris. http://dx.doi. org/10.5962/bhl.title.51973

Thorell T. 1873. Remarks on synonyms of European spiders. Part III: 375-645, C.J. Lundström, Uppsala. http://dx.doi.org/10.5962/bhl.title.69282

Van Keer J. \& Bosmans R. 2009. On some new Harpactea and Stalagtia species from Lesbos, Greece (Araneae: Dysderidae). Acta Zoologica Bulgarica 61: 277-285.

Watrous L.E. \& Wheeler Q.D. 1981. The out-group comparison method of character analysis. Systematic Zoology 30: 1-11.

World Spider Catalog 2016. World Spider Catalog. Natural History Museum, Bern. Available from http://wsc.nmbe.ch, version 17.0 [accessed on 11 Mar. 2016]

Manuscript received: 4 January 2015

Manuscript accepted: 24 March 2016

Published on: 16 August 2016

Topic editor: Rudy Jocqué

Desk editor: Kristiaan Hoedemakers

Printed versions of all papers are also deposited in the libraries of the institutes that are members of the EJT consortium: Muséum national d'Histoire naturelle, Paris, France; Botanic Garden Meise, Belgium; Royal Museum for Central Africa, Tervuren, Belgium; Natural History Museum, London, United Kingdom; Royal Belgian Institute of Natural Sciences, Brussels, Belgium; Natural History Museum of Denmark, Copenhagen, Denmark; Naturalis Biodiversity Center, Leiden, the Netherlands. 